\title{
SEED SELECTION BY DESERT RODENTS: IMPLICATIONS FOR ENHANCING SEEDLING ESTABLISHMENT OF INDIAN RICEGRASS (ACHNATHERUM HYMENOIDES)
}

\author{
William S. Longland ${ }^{1}$ and Lindsay A. Dimitri ${ }^{2}$
}

\begin{abstract}
AвSTRACT.-Seeds of many plant species are dispersed by seed-caching rodents that place groups of seeds in superficially buried scatterhoard caches. A case in point is Indian ricegrass (Achnatherum hymenoides), an important forage plant on arid western rangelands for which seedling recruitment comes largely from scatterhoards made by desert heteromyid rodents. A "diversionary seeding" strategy has been attempted for enhancing Indian ricegrass seedling recruitment by deploying commercially available seeds on the soil surface to divert rodents from recovering scatterhoards of Indian ricegrass seeds. The probability of such a passive restoration approach succeeding is likely affected by the relative desirability to rodents of Indian ricegrass seeds versus diversionary seeds. We conducted laboratory experiments to test preferences of Merriam's kangaroo rat (Dipodomys merriami), a primary dispersal agent of Indian ricegrass seeds, for Indian ricegrass seeds versus seeds of 5 diversionary seed candidates. Indian ricegrass seeds were consistently preferred over only 1 of the 5 alternate seeds in pairwise trials. In multiseed trials that presented all seed types (i.e., Indian ricegrass and the 5 alternates) simultaneously, ranking patterns of individual kangaroo rats varied significantly and Indian ricegrass was not preferred by any of the animals tested. Because individual kangaroo rats differed in seed preferences and all animals consumed certain seed types in greater amounts than they consumed Indian ricegrass, we suggest that using a mixture of different seed types in diversionary seedings is superior to deploying a single type of diversionary seeds. Understanding how population-level niche breadth is affected by dietary variation at the individual level can thus have important management implications.
\end{abstract}

Resumen.-Las semillas de muchas especies de plantas de semillas son dispersadas por el almacenamiento en caché de los roedores que grupos de semillas en superficialmente enterrados scatterhoard cachés. Un ejemplo de ello es proporcionada por una importante planta de forraje en las praderas occidentales áridas, Indian ricegrass (Achnatherum hymenoides), para que la abundancia de renovales scatterhoards viene en gran parte de desierto de roedores se capturo pocos Heteromyidae. Esto se ha traducido en intentos de emplear a un "despiste" estrategia de siembra para mejorar Indian ricegrass reclutamiento de plántulas por implementar las semillas disponibles en el mercado en la superficie del suelo para desviar los roedores de la recuperación de Indian ricegrass scatterhoards las semillas. La probabilidad de este tipo de enfoque posterior restauración pasiva es probable que se vea afectado por la relativa conveniencia de Indian ricegrass semillas semillas diversión frente a los roedores. Hemos llevado a cabo experimentos de laboratorio para comprobar la existencia de las preferencias de una dispersión principal agente de Indian ricegrass semillas, Merriam la rata canguro (Dipodomys merriami), para Indian ricegrass semillas versus las semillas de 5 semillas diversión los candidatos potenciales. Indian ricegrass las semillas fueron sistemáticamente prefirieron en sólo uno de los 5 pares de semillas alternativa los juicios. En varios ensayos de semillas que presentan los tipos de semillas (es decir, Indian ricegrass y los 5 suplentes) al mismo tiempo, clasificación de patrones individuales variaron considerablemente las ratas canguro y Indian ricegrass no fue preferido por cualquier de los animales sometidos a la prueba. Porque las ratas canguro preferencias difieren en las semillas y todos los animales consumen ciertos tipos de semillas en cantidades superiores a las que consumen Indian ricegrass, sugerimos que la utilización de una mezcla de diferentes tipos de semillas en siembras diversión es superior a la implementación de un único tipo de semillas. Comprender cómo nivel de población nicho amplitud se ve afectado por la dieta variación en el nivel de los individuos puede tener importantes consecuencias para la gestión.

Indian ricegrass (Achnatherum hymenoides), a native perennial bunchgrass species that occurs widely throughout arid rangelands of western North America, is an important source of forage for livestock and wildlife, particularly in low-elevation sandy environments (Robertson 1976, Young et al. 1994). Seeds of Indian ricegrass are often included in seeding mixtures applied to arid land restoration plantings
(Jones 1990). However, the success of such efforts has been variable, and Indian ricegrass seeds are more costly than seeds of many alternate forage grasses used more commonly for restoration (Young et al. 1994).

Seed-eating desert rodents, such as species in the family Heteromyidae, are generally the most abundant granivorous vertebrates co-occurring with Indian ricegrass. Among wildland seeds

\footnotetext{
${ }^{1}$ USDA, Agricultural Research Service, Great Basin Rangelands Research Unit, 920 Valley Road, Reno, NV 89512. E-mail: bill.longland@ars.usda.gov

${ }^{2}$ Department of Biology, University of Nevada, Reno, NV 89557.
} 
TABLE 1. Mean size measures (standard deviation in parentheses) for 6 seed types (Indian ricegrass and 5 alternate seed types considered as diversionary seed candidates) included in seed preference trials. African yellow daisy seed is sold commercially as "Nyjer thistle" seed. All measures are based on a sample size of 10 randomly selected seeds per seed type.

\begin{tabular}{lccc}
\hline Seed type & $\begin{array}{c}\text { Mass per seed } \\
(\mathrm{mg})\end{array}$ & $\begin{array}{c}\text { Seed length } \\
(\mathrm{mm})\end{array}$ & $\begin{array}{c}\text { Seed width } \\
(\mathrm{mm})\end{array}$ \\
\hline Indian ricegrass (Achnatherum hymenoides) & $3.3(1.3)$ & $3.83(0.25)$ & $1.44(0.18)$ \\
African yellow daisy (Guizotia abyssinica) & $3.0(1.1)$ & $4.01(0.56)$ & $1.12(0.15)$ \\
Canary grass (Phalaris canariensis) & $6.4(1.9)$ & $4.99(0.44)$ & $1.36(0.15)$ \\
Cracked corn (Zea mays) & $56.8(37.1)$ & $6.80(2.72)$ & $3.16(0.88)$ \\
White millet (Pennisetum miliaceum) & $5.5(1.7)$ & $2.75(0.21)$ & $1.68(0.18)$ \\
White wheat (Triticum aestivum) & $46.2(11.4)$ & $6.82(0.48)$ & $2.76(0.14)$ \\
\hline
\end{tabular}

that are typically available to desert rodents, Indian ricegrass seeds tend to be a highly preferred food resource (McAdoo et al. 1983, Kelrick et al. 1986, Longland and Bateman 1998). However, desert rodents are not solely seed predators. Indian ricegrass seedlings frequently emerge in tight clumps from shallowly buried scatterhoard caches made by heteromyids, and some heteromyid species could thus act as important seed dispersal agents for Indian ricegrass (McAdoo et al. 1983). Using radio-labeled seeds to track seed movement by rodents in a western Nevada field study, Longland et al. (2001) demonstrated that approximately $95 \%$ of Indian ricegrass seedling recruitment was attributable to seeds scatterhoarded by a common and widespread heteromyid species, Merriam's kangaroo rat (Dipodomys merriami). This finding is remarkable considering that rodents recover many, if not the vast majority, of their seed caches for consumption during portions of an annual cycle when seeds are not being produced by plants and are scarce on the soil surface.

Longland and Ostoja (2013) attempted to manipulate the interaction between heteromyid rodents and Indian ricegrass in a passive restoration scheme by using a "diversionary seeding" concept to reduce the probability that rodents would recover and consume Indian ricegrass seed caches (see Sullivan and Klenner 1993, Sullivan and Sullivan 2004). The strategy was to provide a temporary bonanza of inexpensive, commercially available diversionary seeds on the soil surface at the time of year rodents would be feeding largely on cached seeds. The diversionary seeds would reduce the number of Indian ricegrass scatterhoards that rodents recover by diverting their attention to a readily available alternate food source. Although this field study did indeed yield greater Indian ricegrass seedling recruitment on plots where diversionary seeds were applied than on nonseeded plots, Longland and Ostoja (2013) suggested that the type of seed applied as a diversion to rodent recovery of Indian ricegrass caches could have impacted the results and that a more highly preferred diversionary seed would be ideal. The study used white millet (Pennisetum miliaceum) as a diversionary seed. Although millet is clearly preferred by heteromyid rodents to most wildland seeds, its preference ranking when it is paired with Indian ricegrass seeds has varied among studies (compare Kelrick et al. 1986, Longland and Bateman 1998).

We conducted laboratory trials to compare preferences of Merriam's kangaroo rats for Indian ricegrass seeds versus 5 common commercial seed species (Table 1). We used both pairwise choice trials, in which Indian ricegrass seeds were offered together with one of the 5 commercial seeds, and trials in which Indian ricegrass seeds and all 5 commercial seed types were offered simultaneously. Experiments tested whether any of these diversionary seed candidates were consistently eaten in greater quantities than Indian ricegrass seeds among individual animals and whether individuals differed in their apparent seed rankings.

Six Merriam's kangaroo rats (4 females and 2 males) were live-trapped on 17 December 2012 at the Hot Springs Mountains $\left(39^{\circ} 40^{\prime} \mathrm{N}\right.$, $119^{\circ} 05^{\prime} \mathrm{W}$, Churchill County, NV), one of the sites used for previous diversionary seeding studies (Longland and Ostoja 2013). Animals were housed individually at the University of Nevada, Reno, in plexiglass cages with wire tops, a sand substrate, and a small can for security. They were kept under a 12L:12D light cycle and fed a maintenance diet of 
wild-bird seed mix, lettuce, and mealworms. Experimental trials were conducted from 20 December 2012 to 31 January 2013. For each Merriam's kangaroo rat, we conducted 6 trials: 5 pairwise trials with Indian ricegrass seeds versus one of the 5 alternate seed types, plus a trial with all of these seed types offered simultaneously. Consecutive trials for a given individual were separated by 7-12 days. The order of pairwise trials was randomized with respect to the alternate seed types so that different individual kangaroo rats were tested on the alternates in different orders.

For trials, we sieved enough sand to cover the bottom of a $45 \times 25$-cm plexiglass cage $1.5-2.0 \mathrm{~cm}$ deep using a sieve that retained the smallest seed type included in trials. We placed $2.0 \mathrm{~g}$ of Indian ricegrass seeds in a small petri dish at one end of the cage and a separate dish of $2.0 \mathrm{~g}$ of the alternate seed type (for pairwise trials) or of each alternate (for trials with all 5 alternate seed types, yielding a total of $10 \mathrm{~g}$ of alternate seeds) next to the Indian ricegrass dish. A kangaroo rat along with its security can was introduced to the trial cage $1 \mathrm{~h}$ before the 12 -h dark period and returned to its housing cage shortly after the dark period ended the following morning. We sieved contents of the trial cage to remove seeds and shells, separated seeds from shells and different seed types from one another, and weighed remaining intact seeds to determine (by subtraction) the mass of each seed type eaten.

We conducted $t$ tests for paired comparisons (PROC TTEST; SAS 2012) on differences between masses of Indian ricegrass seeds and alternate seeds consumed in pairwise trials. These tests were conducted for all individual kangaroo rats and all alternate seed types combined, for each alternate seed type (using trials for individual kangaroo rats as replicates), and for each individual kangaroo rat (using trials for each alternate seed type as replicates). We used PROC MIXED to conduct a one-way analysis of variance (ANOVA) on data from the experiment that presented all 6 seed types simultaneously: trials using the 6 individual kangaroo rats were replicates, mass of seeds consumed was the dependent variable, and seed type was the independent class variable. In the latter analysis, we also examined least squares means for each seed type and differences between least squares means for pairs of seed types for evidence of significant preferences.

Among all trials with paired seed types, a significantly greater mass of Indian ricegrass seeds was consumed than that of all alternate seed types combined (mean mass of Indian ricegrass seeds consumed per trial $=1.43 \mathrm{~g}$ [SD 0.41], alternate seeds $=1.13 \mathrm{~g}$ [SD 0.56]; $t=2.05, \mathrm{df}=29, P=0.0498)$. However, considering alternate seed types separately, the only trials that yielded a significant difference in mass of seeds consumed were those in which the alternate seed type was African yellow daisy $(t=9.54$, $\mathrm{df}=5, P=0.0002)$, which was consumed in much smaller amounts than Indian ricegrass (Fig. 1). Masses of Indian ricegrass consumed versus alternate seeds in paired trials did not approach statistical significance $(P>0.40$ in all cases). Among the 6 kangaroo rats tested in paired trials, only individual \#55 showed a significant preference for Indian ricegrass across the pooled 5 alternate seed types; no animals consistently favored the alternates over Indian ricegrass (Table 2).

ANOVA on trials with all 6 seed types presented simultaneously indicated significant variation among seed types in masses consumed $\left(F_{5,30}=3.18, P=0.0202\right.$; Fig. 2$)$. Least squares means indicated that all seed types were consumed in amounts that differed significantly from 0 , except for African yellow daisy $(t=1.76$, df $=30, P=0.0890)$ and white wheat $(t=1.58, \mathrm{df}=30, P=0.1248)$. Differences of least squares means did not indicate any significant patterns involving Indian ricegrass in the multiseed trials, although both cracked corn and white millet were consumed in greater amounts than either African yellow daisy or white wheat $(P \leq 0.015$ in these cases).

We found a marginally significant preference for Indian ricegrass seeds in paired seed preference experiments when trials were combined across all the alternate seed types and all individual kangaroo rats tested. This finding illustrates the challenge of identifying a seed that is ideal for use in diversionary seedings aimed at enhancing Indian ricegrass seedling emergence from rodent scatterhoards. In testing alternate seed types separately, however, Indian ricegrass was significantly preferred over only one of the 5 alternate seeds, African yellow daisy (typically sold 


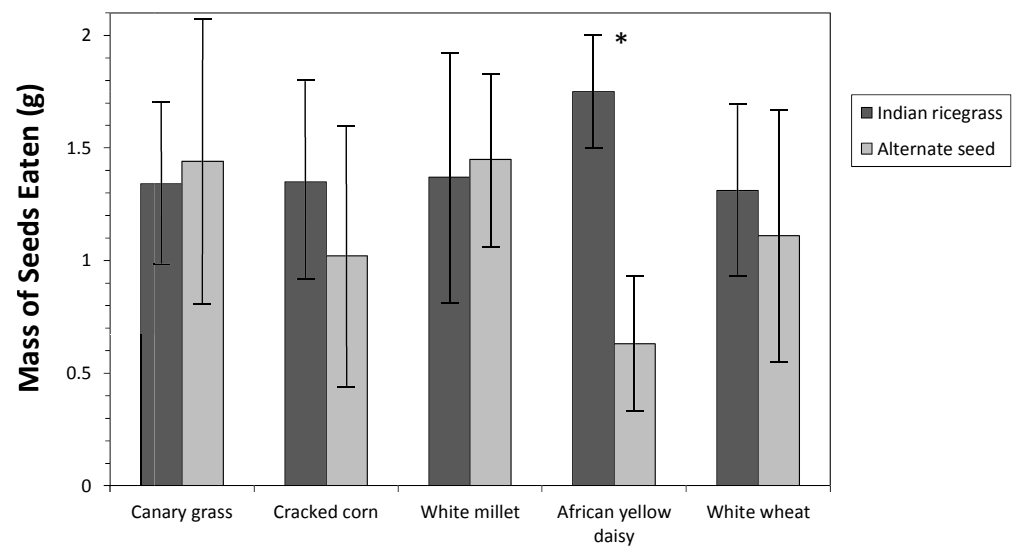

Alternate Seed Type

Fig. 1. Mean mass $( \pm \mathrm{SD})$ of Indian ricegrass seeds and of 5 alternate seed types consumed by Merriam's kangaroo rats in pairwise seed selection trials. An asterisk (*) above a pair of bars indicates that the mass of seeds consumed differed significantly $(P=0.0002)$ between Indian ricegrass and that alternate seed type.

TABLe 2. Mean mass (g) eaten by 6 Merriam's kangaroo rats from $2.0 \mathrm{~g}$ Indian ricegrass seed and $2.0 \mathrm{~g}$ of an alternate seed type in trials with paired seed types. Numbers in parentheses are standard deviations.

\begin{tabular}{lccrrr}
\hline & \multicolumn{2}{c}{ Mass $(\mathrm{g})$ of seed eaten per trial } & & & \\
Animal ID & Indian ricegrass & Alternate seed & $t$ & df & $P$ \\
\hline 38 & $1.40(0.37)$ & $1.17(0.77)$ & 0.47 & 4 & 0.660 \\
51 & $0.96(0.38)$ & $1.04(0.25)$ & 0.16 & 4 & 0.822 \\
52 & $1.58(0.38)$ & $1.52(0.47)$ & 0.79 & 4 & 0.883 \\
53 & $1.65(0.49)$ & $1.33(0.57)$ & 0.90 & 4 & 0.471 \\
54 & $1.40(0.39)$ & $1.19(0.46)$ & 4.72 & 4 & 0.418 \\
55 & $1.57(0.18)$ & $0.53(0.41)$ & 4 & 0.009 \\
\hline
\end{tabular}

commercially under the name Nyjer thistle), suggesting that this seed would be a poor choice for a diversionary seeding. Though there were no alternate seed types that were significantly and consistently preferred over Indian ricegrass among individual kangaroo rats, both canary grass seed and white millet seed were taken in greater quantities than Indian ricegrass in paired seed trials (Fig. 1). Moreover, 2 of the 6 animals tested consumed more alternate seeds in paired trials with both cracked corn and white wheat, suggesting that individual animals varied in seed ranking patterns. This assumption was reinforced by analyses of paired seed trial results for individual animals. Only one of 6 animals tested showed a consistent preference for Indian ricegrass seeds across all alternate seed types, whereas other animals tended to vary in relative amounts of Indian ricegrass versus the various alternate seeds consumed (Table 2).
In trials with all seeds offered simultaneously, Indian ricegrass was only the fourthranked seed type when data were combined for all animals tested; cracked corn, white millet, and canary grass seed were all consumed in greater quantities (Fig. 2). Furthermore, Indian ricegrass was not the highestranking seed for any individual kangaroo rat tested in these multiseed trials. Individual animals exhibited significant variation in relative amounts of the 6 seed types consumed. This variation prevented the emergence of consistent ranking patterns among individual kangaroo rats, and it may have important implications for diversionary seeding strategies. In particular, our results suggest that a combination of alternate seed types may be superior to a single seed type in diversionary seedings intended to suppress rodent consumption of Indian ricegrass seed caches.

The overall effect of seed predation by a rodent population is spread more diffusely 


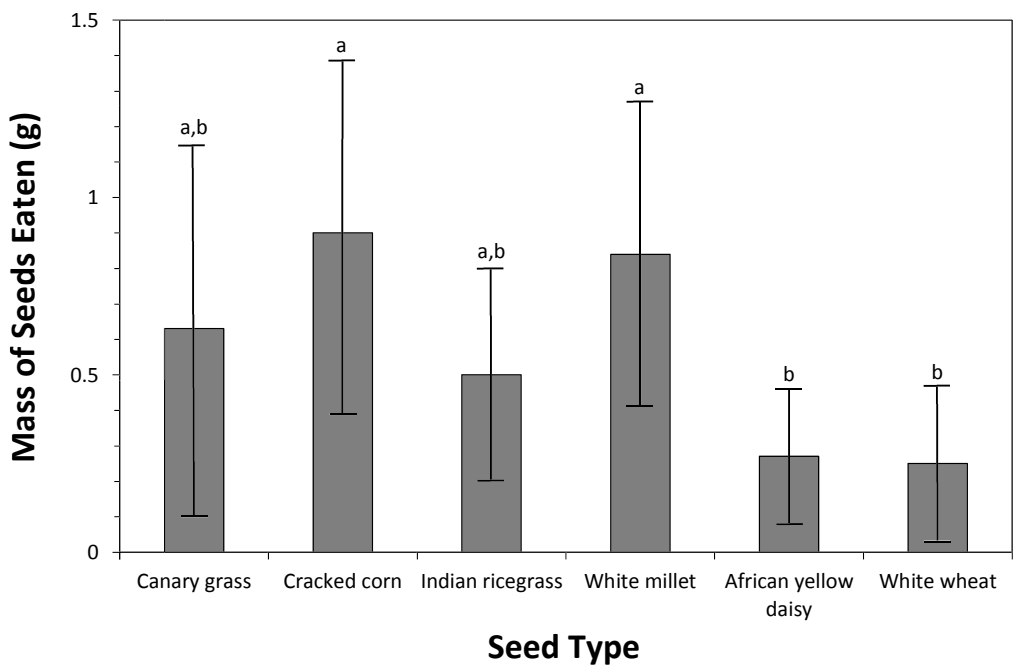

Fig. 2. Mean mass $( \pm \mathrm{SD})$ of Indian ricegrass seeds and 5 commercial seed types consumed by Merriam’s kangaroo rats in multiseed selection trials. Letters above bars denote statistical significance; seed types differed significantly $(P<0.015)$ in consumption by kangaroo rats if their respective bars do not share a letter in common.

among the various seed types available when the population is composed of individuals with varying preferences. The idea that populations with wider ecological niches tend to be comprised of individuals with narrower but varying niches was formalized as the "niche variation hypothesis" (Van Valen 1965). Although this hypothesis was initially proposed to address morphological variation, it has been extended to considerations of behavioral variation as well, suggesting that populations with generalized diets may be comprised of individuals that specialize on differing dietary items (Bolnick et al. 2007). We found no strong evidence of individual specialization in this study. Of the 6 Merriam's kangaroo rats included in our seed selection experiments, only one individual showed any evidence of a specialized preference for Indian ricegrass in pairwise seed choice trials, and that individual did not exhibit such a preference in the multiseed choice experiment. However, substantial individual variation in proportions of alternate seeds included in the diet would still result in expanded niche breadth at the population level. Individual behavioral variation (e.g., in seed caching behavior) has been previously demonstrated in Merriam's kangaroo rats (Jenkins et al. 1995, Murray et al. 2006, Dochtermann and Jenkins 2007).
Some of the commercial seeds we included in our experiments may be suitable candidates for inclusion in a diversionary seed mixture for Indian ricegrass restoration efforts. Canary grass seeds, white millet seeds, and cracked corn all compared well with Indian ricegrass seeds in both pairwise choice tests and multiseed tests. By contrast, African yellow daisy seeds were largely rejected in both types of tests. White wheat compared well with Indian ricegrass in paired trials but was the least consumed seed in multiseed trials, so its potential utility as a diversionary seed is unclear. We have certainly not exhausted the list of diversionary seed candidates in our studies, and many others could be tested. Moreover, diversionary seeding strategies may have application in restoration efforts aimed at establishing plant species other than Indian ricegrass. Seedlings of many plant species are dispersed by scatterhoarding rodents (Vander Wall 1990), but the utility of diversionary seeding may not even be restricted to such species. For example, diversionary seeding using inexpensive commercial seeds may reduce rodent seed predation rates on more costly target seeds that have been drill-seeded in restoration efforts. A primary consideration in applying a diversionary seeding strategy is the relative seed preference rankings of the local granivorous rodent community. Of course, it is also 
essential to confirm that any diversionary seed candidate will not establish a reproducing population where it is deployed. Because the commercial seeds we employed are generally grown under irrigation, it is unlikely that diversionary seed reproduction would be a problem in the arid environments typical of Indian ricegrass.

\section{ACKNOWLEDGMENTS}

We thank Eugene Schupp and an anonymous reviewer for thoughtful comments that helped improve our manuscript and Josh Holman for assisting with seed choice experiments. This paper is a contribution of the USDA, ARS, Great Basin Rangelands Research Unit, Reno, NV.

\section{Literature Cited}

Bolnick, D.I., R. Svanback, M.S. Araujo, and L. Persson. 2007. Comparative support for the niche variation hypothesis that more generalized populations also are more heterogeneous. Proceedings of the National Academy of Sciences (USA) 104:10075-10079.

Dochtermann, N.A., And S.H. Jenkins. 2007. Behavioural syndromes in Merriam's kangaroo rats (Dipodomys merriami): a test of competing hypotheses. Proceedings of the Royal Society B: Biology 274:2343-2349.

Jenkins, S.H., A. Rothstein, And W.C.H. Green. 1995. Food hoarding by Merriam's kangaroo rats: a test of alternative hypotheses. Ecology 76:2470-2481.

JoNES, T.A. 1990. A viewpoint on Indian ricegrass research: its present status and future prospects. Journal of Range Management 43:416-420.

Kelrick, M.I., J.A. MacMahon, R.R. Parmenter, and D.V. Sisson. 1986. Native seed preferences of shrubsteppe rodents, birds, and ants: the relationships of seed attributes and seed use. Oecologia 68:327-337.
LONGLAND, W.S., AND S.L. Bateman. 1998. Implications of desert rodent seed preferences for range remediation. Journal of Range Management 51:679-684.

LONGLAND, W.S., S.H. Jenkins, S.B. Vander WaLL, J.A. VEech, AND S. Pyare. 2001. Seedling recruitment in Oryzopsis hymenoides: are desert granivores mutualists or predators? Ecology 82:3131-3148.

LONGLand, W.S., and S.M. Ostoja. 2013. Ecosystem services from keystones species: diversionary seeding and seed-caching desert rodents can enhance Indian ricegrass seedling establishment. Restoration Ecology 21:285-291.

McAdoo, J.K., C.C. Evans, B.A. Roundy, J.A. Young, AND R.A. Evans. 1983. Influence of heteromyid rodents on Oryzopsis hymenoides germination. Journal of Range Management 36:61-64.

Murray, A.L., A.M. Barber, S.H. Jenkins, and W.S. LONGLAND. 2006. Competitive environment affects food-hoarding behavior of Merriam's kangaroo rats (Dipodomys merriami). Journal of Mammalogy 87: 571-578.

RoberTson, J.H. 1976. The autecology of Oryzopsis hymenoides. Mentzelia 1:18-21.

SAS. 2012. Version 9.4. SAS Institute, Cary, NC.

Sullivan, T.P., AND W. Klenner. 1993. Influence of diversionary food on red squirrel populations and damage to crop trees in young lodgepole pine forest. Ecological Applications 3:708-718.

Sullivan, T.P., AND D.S. Sullivan. 2004. Influence of a granivorous diversionary food on population dynamics of montane voles (Microtus montanus), deer mice (Peromyscus maniculatus), and western harvest mice (Reithrodontomys megalotus). Crop Protection 23:191-200.

VAN VALEN, L. 1965. Morphological variation and width of ecological niche. American Naturalist 99:377-390.

VANDER WALL, S.B. 1990. Food hoarding in animals. University of Chicago Press, Chicago, IL.

Young, J.A., R.R. Blank, W.S. LONGLAND, and D.E. PalmQuist. 1994. Seeding Indian ricegrass in an arid environment in the Great Basin. Journal of Range Management 47:2-7.

Received 9 October 2015 Accepted 10 March 2016 